\title{
WILL CASHLESS PAYMENT BECOME CONSUMER'S TRANSACTION HABIT IN THE "NEW NORMAL" ERA?
}

\author{
Refius Pradipta Setyanto ${ }^{1}$, Wenti Ayu Sunarjo ${ }^{2}$ \\ 'refius.setyanto@unsoed.ac.id \\ Universitas Jenderal Soedirman \\ J1. Profesor DR. HR Boenyamin No.708, Kec. Purwokerto Utara, Banyumas, Jawa Tengah
}

received: 6/12/20; revised: 10/12/20; approved: 28/6/21

\begin{abstract}
The purpose of this study was to find out whether or not new habit, cashless transaction, would still be used after the Covid-19 pandemic or in the new normal era, considering that this was a situational or temporary factor. The population of this research was individual consumers who were currently more likely to have higher intensity in cashless transactions than they did before the pandemic. This research was a study conducted during the Covid-19 pandemic in Indonesian society by examining the effect of perceived security, perceived risk, facilitating condition, Self-Efficacy of trust in online payments, and the use of cashless on Usage Continuance intention. The results of this study with 594 tested samples were two insignificant correlations. They were perceived risk toward trust in online payments and self-efficacy on usage continuance intention. These findings could support a wide range of stakeholders - both first movers/ pioneers and newcomers to the e-money segment, as the information about promotion and selection of the right market for their products.
\end{abstract}

Keywords: cashless; perceived safety; perceived risk; facilitating conditions; self efficacy

\section{INTRODUCTION}

During its development, cashless payment system is greatly influenced by advances in technological developments and changes in people's lifestyles. In line with the opinion $(\mathrm{Ng} \& \mathrm{Ng}, 2017)$ that the journey to a cashless society requires the consideration of many factors, including a focus on the category of low-value merchants, merchant discount rates, domestic market size, payment interface, role of card mass transit, and strategic government intervention.

Nowadays, the development of cashless payment instruments is progressing very rapidly in line with developments in technology and payment system strategies which have recently had a major impact on the stakeholders involved in the payment system (Dinh, et al., 2018). With the support of increasingly advanced technology, users and providers of non-cash payment system services are continuously looking for alternatives to non-cash payment instruments that are more efficient and safer. Supporting the level of security from cashless (Yang, 2015) implied that for service providers, it is necessary to increase information transparency, such as offering more information about fulfillment or completion, privacy protection, account security, technology security, etc.

In addition, changes in trends and community lifestyle as well as the increased lifestyle efficiency require the availability of fast means so that distance and time limits can be reduced. (Dinh, et al., 2018) said that the determinants influenced their adoption of mobile payment services in order to gain consumer motivation and limitations related to the implementation of their mobile payments.

Even though cashless services have achieved great success in many countries, Indonesia has not achieved the same level of cashless absorption. Problems that are faced in Indonesia, particularly banking and logistics services include common terms: weak formal institutions and legal structures; a business with considerable influence; uneven internet and telephone network coverage (Azali, 2016). In the last few years, there has been seen the development of cashless transactions in Indonesia. This occurs because more and more centers of economic activity provide cashless payment facilities. There are still limited cashless payments in Indonesia. However, they are developing, including credit cards, debit cards, ATMs, which are generally well known by the wider community. This development is caused by various factors such as ecological, economic, social, technological, political, and cellular networks (Sheller, 2004). 
Currently, the world is fighting the conditions of the COVID-19 Pandemic. This condition has forced many stakeholders to be able to undergo a significant transformation, looking for solutions to their activity processes, and especially optimizing the use of technology to maintain stable conditions. Transformations during the Covid-19 pandemic are required to follow the landscape of new guidelines and procedures, especially for the sake of breaking the chain of virus transmission. What we know has changed a lot, such as studies (Dwivedi, et al., 2020) which offered collective insights into the many major problems and fundamental complexities that affect life during the COVID-19 pandemic through information systems and technological perspectives.

Regarding the information systems and technology needed during the Covid-19 pandemic, it is in line with one of the topics (Allam, 2020) how COVID-19 provided increasing pressure to switch from a cash-based system to a cashless system and showed how giant payments and ICT companies have long been active in providing the basic structure for this transition. This is in line with what was stated by (Friedman, 1999), that the development of information technology would have implications for the reduced role of cash-based in payment transactions, which could minimize direct contact with money or cash.

In particular, the researchers applied the theory of reasoned action point of view proposed by (Lin \& Wang, 2006) as the theory in this article, where trust can lead to attitudes, which in turn influence behavioral intentions in new normal patterns. We supposed a trust transfer process that could ultimately influence cashless continuance usage intentions (Cao, 2017).

Perceived security turned out to play an important role in switching the intention into the need to use something (Montoro, et al., 2019). It is inseparable from the safety factor. If there is perceived security, trust will arise. Furthermore, to predict and to explain perceived security (You, et al., 2018), the results of the inter-subject experiment showed that perceived security could be increased. This sense of security can be formed well in such condition; the more someone trusts that there is security guarantee by using it, the more likely that person wants to use it again. Studies conducted (Noort, et al. 2008) showed that online security cues reduce consumers' risk perceptions.

Bauer (1960) suggested that most consumer procurement behavior might be risky because purchasing decisions could lead to unpredictable consequences. According to the results of the study (Ozturk, 2016) risk perception negatively affected perceptions of usefulness and ease of use. It means that perceived risk is negatively related to utility and intention to use. In addition to the original UTAUT antecedents, studies (Sobti, 2019) found perceived risk was also considered a potential antecedent of behavioral intention. Another research study stated that the relationship between trust and perceived risk was not parallel but serial, and trust affected consumer intentions through perceived risk (Yang, 2015).

Venkatesh, et al. (2003) the extent to which someone trusted that organizational and technical infrastructure existed to support the use of the system, with considerations to facilitate conditions that also included the knowledge, abilities, and resources of users (Zhou, et al., 2010). (Odoom \& Kosiba, 2020). Furthermore (Gupta et al., 2019) tested an integrated model to explain decisions in adopting payment services, it was said that the most significant factor explaining the intention of adopting payment bank services included facilitating conditions. Meanwhile (Oliveira, et al., 2016) examined the impact of facilitating conditions on the adoption of mobile payment technology, but they failed to support the impact. Trust enjoyed wide acceptance among primary facilitators on relationship development, and successful relationship development demanded an understanding of what lead to the trust tendency (Franklin \& Marshall, 2019).

Bandura (1997) suggested that self-efficacy refered to people's assessment of their ability to be able to organize and to do the actions needed to achieve specific goals. Curtice and Norris (2004) suggested that the Internet provides various kinds of information, which can increase the effectiveness of society (Lee and Huang, 2014). Moeller, et al. (2014) mentioned news in the media regarding internal efficacy and found that being active in the online information communication process had the strongest impact on internal rights. This is very clearly related to the trust that arises in them.

The findings (Wang, 2020) revealed that self-efficacy in cashless payments was a key determinant of the intention to use cashless payments. Another context of mobile applications and services is the existence of empirical support that has been found about a positive relationship between self-efficacy and the adoption of behavioral intentions or actual behavior (Alalwan, et al. 2016).

Trust could provide subjective guarantee to users positivity in the future (Gefen \& Straub, 2003). Trust also enabled users to believe that service providers had the ability and integrity to provide good quality cashless payment services. Other studies had also identified the effect of trust on perceived usefulness (Yoon, 2009) so that trust could affect cashflow. When users have developed trust in cashless payments, they might simultaneously form a positive attitude in the form of a testimonial about their experience (Lin \& Wang, 2006). Customer trust was also an important component in influencing anticipation of future interactions (Doney \& Cannon, 1997).

Continuance Intention is an intention arising from users to continue to use application services as a willingness to continue to transact cashless (Bhattacherjee, et al., 2008). Continuance Intention is an intention to continue 
to carry out an activity after it has been previously adopted (Chen \& Xianjun, 2015). According to information, "Continuance Intention refers more to an individual's assessment of wanting to buy or reuse a product or service in other activities, taking into account the possibility of the current state or situation" (Ahmad, et al. 2010). Monica \& Briliana (2019) suggested that Continuance Intention can be interpreted as a person's intention to start using technology applications continuously. As stated by (Hepola, et al. 2016) positive feelings about a product or service, such as the use of cashless payment applications, lead to an increased intention to continue using cashless based services.

\section{METHODS}

The population of this research was individual consumers who were currently more likely to have higher cashless transactions intensity than before the pandemic. Researchers did not define quantitative limits in determining the intensity. Researchers based on the judgment of respondents in assessing the intensity of use before and during the pandemic related to the use of these cashless transactions. The research population was infinite so that the research was based on the rule of thumb in determining the sample size. Researchers obtained 594 sample sizes which characteristics were quite heterogeneous (Table 1).

\begin{tabular}{|c|c|c|c|}
\hline Demographics & Categories & Frequency & Percentage \\
\hline \multirow[t]{2}{*}{ Gender } & Males & 274 & 46.1 \\
\hline & Females & 320 & 53.9 \\
\hline Total & & 594 & 100.0 \\
\hline \multirow[t]{5}{*}{ Educational Background } & Doctoral & 22 & 3.7 \\
\hline & Master & 169 & 28.5 \\
\hline & Bachelor & 265 & 44.6 \\
\hline & Degree & 21 & 3.5 \\
\hline & Senior High School & 117 & 19.7 \\
\hline Total & & 594 & 100.0 \\
\hline \multirow[t]{5}{*}{ Age } & $17-25$ years old & 184 & 31 \\
\hline & 26-34 years old & 139 & 23.4 \\
\hline & $35-43$ years old & 125 & 21 \\
\hline & 43-52 years old & 101 & 17 \\
\hline & $>53$ years old & 45 & 7.6 \\
\hline Total & & 594 & 100.0 \\
\hline \multirow[t]{9}{*}{ Profession } & Governance & 55 & 9.3 \\
\hline & Lecturer & 127 & 21.4 \\
\hline & Teacher & 56 & 9.4 \\
\hline & Enterpreuner & 45 & 7.6 \\
\hline & Employee & 114 & 19.2 \\
\hline & College & 145 & 24.4 \\
\hline & Student & 2 & 0.3 \\
\hline & Labour & 7 & 1.2 \\
\hline & Others & 43 & 7.2 \\
\hline Total & & 594 & 100.0 \\
\hline
\end{tabular}

\section{RESULTS}

The standard SEM analysis solution in Figure 1 showed the strength of the relationship effect among constructs. Testing of the fit model showed that only two testing criteria met the requirements or achieved a fit model, namely RMSEA with a value of 0.065 (cut off value $\leq 0.08$ ) and GFI with a value of 0.918 (cut off value $\geq 0.90$ ). Meanwhile, the other categories did not achieve the required cut off value, such as Chi-square (430.036), AGFI with a value of 0.886 (cut off value $\geq 0.90$ ), CMIN / DF with a value of 3.496 (cut off value $\leq 2.00$ ), TLI with a value of 0.918 (cut off value $\geq 0.95$ ), and CFI with a value of 0.934 (cut off value $\geq 0.95$ ). Although not all index values were met, the fit model was generally said to be marginal. 


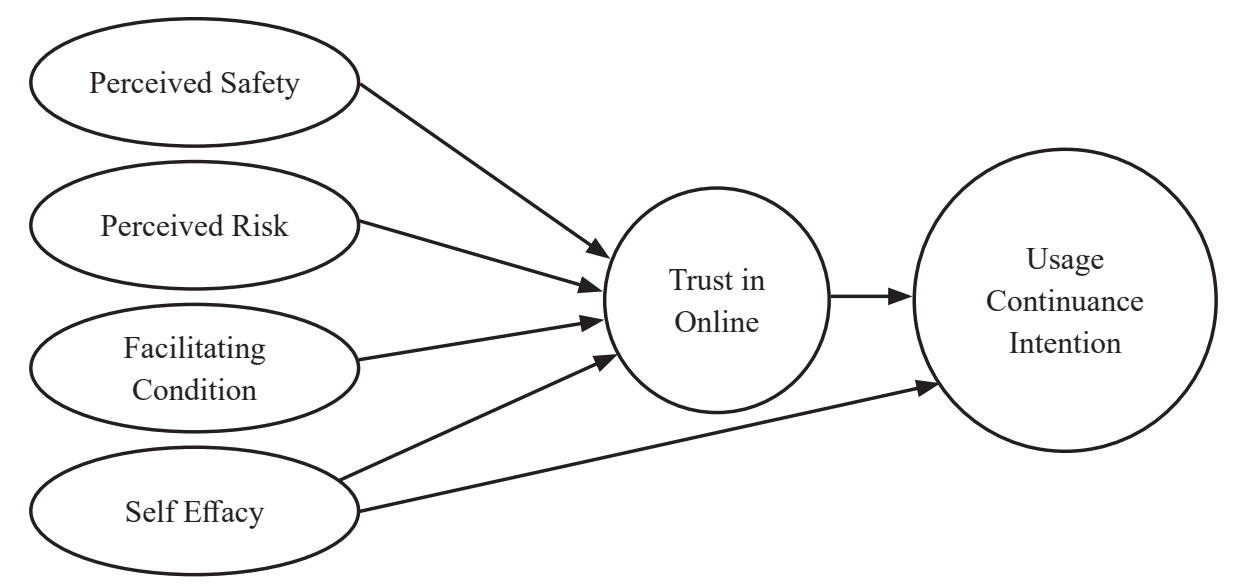

Figure 1. Research Framework

The validity and reliability measurements were summarized in the Table 2 .

Table 2. Confirmatory Factor Analysis

\begin{tabular}{|c|c|c|c|c|}
\hline & Construct and Indicator & $\begin{array}{l}\text { Factor } \\
\text { Loading }\end{array}$ & $\begin{array}{l}\text { Composite } \\
\text { Reliability }\end{array}$ & AVE \\
\hline \multirow[t]{3}{*}{ A. } & Perceived Safety (Montoro et al., 2019) & & & \\
\hline & 1. I feel secure when I am doing cashless payment transaction. & 0,792 & 0,818 & 0,692 \\
\hline & 2. In my opinion, doing cashless transaction is the best solution in this current era. & 0,710 & & \\
\hline \multirow[t]{4}{*}{ B. } & Perceived Risk (Muñoz-Leiva et al., 2017) & & & \\
\hline & 1. For me, decision to use cashless payment is more risky. & 0,818 & 0,965 & 0,901 \\
\hline & 2. Using cashless payment can endanger my own privacy. & 0,774 & & \\
\hline & 3. Cashless payment has more uncertainty. & 0,668 & & \\
\hline \multirow[t]{4}{*}{ C. } & Facilitating condition (Gupta et al., 2019) & & & \\
\hline & 1. I have the necessary skills to use cashless payment. & 0,920 & 0,822 & 0,645 \\
\hline & 2. I have the necessary knowledge to use cashless payment & 0,883 & & \\
\hline & 3. Cashless payment is compatible with system or application which I use. & 0,817 & & \\
\hline \multirow[t]{4}{*}{ D. } & Self-efficacy (Wang, 2020) & & & \\
\hline & 1. I can only use cashless payment if there is help from someone else. & 0,638 & 0,839 & 0,530 \\
\hline & $\begin{array}{l}\text { 2. I can easily ask for help to my trusted person if there is a problem in using } \\
\text { cashless payment. }\end{array}$ & 0,623 & & \\
\hline & 3. I can use cashless payment if someone shows me how to use it first. & 0,673 & & \\
\hline \multirow[t]{4}{*}{ E. } & Trust in online payment (Muñoz-Leiva et al., 2017) & & & \\
\hline & 1. I believe future transaction will use cashless payment. & 0,668 & 0,8 & 0,572 \\
\hline & 2. I trust that all my data are secure while using cashless payment & 0,689 & & \\
\hline & 3. I believe using cashless payment is one of the forms of social distancing. & 0,441 & & \\
\hline \multirow[t]{4}{*}{ F. } & Usage continuance intention (Beldad \& Citra Kusumadewi, 2015) & & & \\
\hline & 1. I intend to continue use cashless payment. & 0,863 & 0,840 & 0,656 \\
\hline & $\begin{array}{l}\text { 2. My intention is to continue using cashless payment because of its security and } \\
\text { its convinience rather than using other alternatives }\end{array}$ & 0,846 & & \\
\hline & $\begin{array}{l}\text { 3. If I could, I would like to stop using cash payment which has high risk in this } \\
\text { new normal era. }\end{array}$ & 0,682 & & \\
\hline
\end{tabular}

Construct Reliability: $\geq 0,70$

Variance Extract: $\geq 0,50$

Alpha Coefficient (Variable alpha): $\geq 0,60$ 
Confirmation factor analysis (CFA) was conducted to test the validity of the data measurement model. Overall, the results showed that the measurement model has met the appropriate statistical criteria, all loading variable values were above $\geq 0.5$, then all variables were valid for usage continuity utility or it could be said that all indicators passed the validity test. The result of reliability value was all variables (observed) were valid, with the construct reliability value was above 0.70 and the extract variance was above 0.50 . Average Variance Extracted (AVE) for each variable was above 0.5 and the loading factor value was also above 0.5 with a significance at the $5 \%$ level, the results were in line with the reliability of the indicator level. The results of the hypothesis testing were as follows.

The following were the results. Perceived safety positively affected trust in online payment, or the higher security that the consumer felt, the more trust that the consumer had in the online transaction mode. Perceived risk had no significant effect on trust in online payment (prob 0.06), the higher the consumer's risk in using cashless, the lower the trust in online transactions. Facilitating conditions had a significant and positive effect on trust in online payments. The higher the situation in facilitating the use of cashless transactions, the higher consumer trust in online transactions. Self-efficacy had a positive and significant effect on trust in online payments, so increasing self-efficacy would also have an impact on increasing consumer trust in online transactions. Trust in online payments had a positive and significant effect on usage continuance intention, so the existence of consumer trust in online transactions would increase the intention to use cashless sustainably. Self-efficacy did not have a positive and significant effect on usage continuance intention, so the increased self-efficacy of consumers to use cashless would encourage the intention to use cashless sustainably.

\section{DISCUSSIONS}

This study aimed to test empirically the sustainability of cashless use in the future or the intention to continue using cashless among consumers in Indonesia. Our research addressed the problem currently being discussed, whether or not cashless transactions in Indonesia would continue to be used in the new normal era, regarding that this was a situational or temporary factor.

Based on our determination of the factors that influence the sustainable use of cashless, the results required scientific implications for future research, and practical implications for both cashless practitioners and users. The results which were obtained from our research modeling were as follow; perceived safety positively affected trust in online payment, or the more secure the consumer felt, the higher trust that were felt by consumers in the online transaction mode. Perceived risk have negative effect on trust in online payment, the higher the consumer's risk in using cashless, the lower the trust in online transactions. Facilitating conditions had a positive effect on trust in online payments. The higher the situation in facilitating the use of cashless transactions, the higher consumer trust in online transactions. Self-efficacy had a positive effect on trust in online payments, so increasing self-efficacy would also have an impact on increasing consumer trust in online transactions. Trust in online payments had a positive effect on usage continuance intention, so the existence of consumer trust in online transactions would increase the intention to use cashless sustainably. Self-efficacy did not have a positive effect on usage continuance intention, so the increased self-efficacy of consumers to use cashless would encourage the intention to use cashless sustainably. This was in line with the results of the study by (Wang, 2020).

\section{CONCLUSIONS}

This study explored the modification of the theory of acceptance and use of technology (UTAUT) which was modified by a complex quantitative study with research locus in Indonesia. In this paper, the researchers tried to explore Indonesian consumers in using cashless during a pandemic and whether or not cashless usage could be sustainable in the new normal era. As we knew, Indonesia had a large and diverse population. The majority of the population were unbanked or people who did not have bank account, and did $\backslash$ not have access to fixed internet channels or limited state banking services. Cashless payment systems such as credit cards were used by less than 10 percent of Indonesia's population (Azali, 2016).

Such as research conducted Monica \& Briliana (2019), the application designed by the Indonesian "GOFOOD" is one of the superior services of the "GO-JEK" application, which is a service provider through a mobile application that has clear information. So that when the user operates the application it will be very helpful and easy because the process stages from ordering to transactions are carried out very clearly, by using the GO-FOOD application, consumers do not need to bother coming to the desired restaurant, seeing the current condition of big cities which often experience traffic jams especially when they are currently in a state of the Covid-19 pandemic

However, with the Covid-19 pandemic affecting more than 200 countries in the world recently, not only applications can make it easier, but people are increasingly aware of reducing the use of cash when making 
transactions as an attempt to break into chain virus, so cashless now plays an important role in driving the reduction of cash payments. Cashless payments are a payment solution that is cheap, efficient and relatively safe (Yang, 2015), especially when it is important for health and safety. To achieve objective research, we developed and tested a series of hypotheses using survey data for 594 cashless users in Indonesia.

This study makes an important contribution to theory / research by showing that the higher the perceived security that is felt by consumers in using cashless, the higher the trust from consumers in online transaction modes. In this case, cashless service providers can prioritize security for their customers, so that with better security, people will trust more and want to use cashless for its security guarantees.

Furthermore, facilitation conditions related to cashless are also needed. As a result, there will be an increase in cashless transactions. The better the facilitation, the higher the consumer's trust in online transactions. If there is consumer trust in online transactions, the intention of consumers in using cashless sustainably will increase.

This study was conducted with an online survey of 594 respondents who were cashless users from across several cities in Indonesia. Different backgrounds of respondents can actually generalize the results of our research on the sustainable use of cashless in the future.

\section{REFERENCES}

Ahmad, N., Omar, A., Ramayah, T. 2010. Consumer Lifestyles and Online Shopping Continuance Intention. Business Strategy Series, 11(4), 227-243. Doi:10.1108/17515631011063767

Alalwan, A. A., Dwivedi, Y. K., Rana, N. P., \& Williams, M. D. 2016. Consumer Adoption of Mobile Banking in Jordan: Examining The Role of Usefulness, Ease of Use, Perceived Risk and Self-Efficacy. Journal of Enterprise Information Management, 29(1), 118-139. Https:// Doi.Org/10.1108/JEIM-04-2015-0035.

Allam, Z. 2020. The Forceful Reevaluation of Cash-Based Transactions by COVID-19 and Its Opportunities to Transition to Cashless Systems in Digital Urban Networks. Surveying The Covid-19 Pandemic and Its Implications, 107-117. Https://Doi.Org/10.1016/B978-0-12-824313-8.00008-5

Azali, K. 2016. Cashless In Indonesia: Gelling Mobile E-Frictions? Southeast Asian Economies, 33(3), 364-386.

Bandura, A., 1997. The Anatomy of Stages of Change. American Journal of Health Promotion: AJHP, 12(1), pp.8-10.

Bauer, R. 1960. Consumer Behavior as Risk Taking. in Hancock, R.S. (Ed.), The 43rd Conference of The American Marketing Association (Pp. 389-398). Chicago, IL: American Marketing Association.

Beldad, A. and Kusumadewi, M.C., 2015. Here's My Location, for Your Information: The Impact of Trust, Benefits, and Social Influence on Location Sharing Application Use Among Indonesian University Students. Computers in Human Behavior, 49, Pp.102-110. Https://Doi.Org/10.1016/J.Chb. 2015.02.047

Bhattachherjee, A., Johan, P. And Clive, S. 2008. Information Technology Continuance: A Theoretic Extension and Empirical Test, The Journal of Computer Information Systems, Vol.49, No.1, Pp.17-26

Cao, X. 2017. Understanding Mobile Payment Users' Continuance Intention: A Trust Transfer Perspective. 71502168. Https://Doi.Org/10.1108/Intr-11-2016-0359

Chen, M. And Xianjun, Q. (2015), Members' Satisfaction And Continuance Intention: A Socio-Technical Perspective, Industrial Management \& Data Systems, Vol.155, Iss 6, Pp.1132-1150

Curtice, J. and Norris, P., 2004. e-Politics? The Impact of The Internet on Political Trust and Participation. British Social Attitudes: the 21st. report.

Dinh, V. S., Nguyen, H. V., \& Nguyen, T. N. 2018. Cash or Cashless?: Promoting Consumers' Adoption of Mobile Payments in An Emerging Economy. Strategic Direction, 34(1), 1-4. Https://Doi.Org/10.1108/ SD-08-2017-0126

Doney, P., \& Cannon, J. 1997. An Examination of The Nature of Trust in Buyer-Seller Relationships. Journal Of Marketing, 61(2), 35-51.

Dwivedi, Y. K., Hughes, D.L., Coombs, C., Constantiou, I., Duan, Y., Edwards, J.S., Gupta, B., Lal, B., Misra, S., Prashant, P. and Raman, R., 2020. Impact of COVID-19 Pandemic on Information Management Research and Practice: Transforming Education, Work and Life. International Journal of Information Management, 55, p.102211. Https://Doi.Org/10.1016/J. Ijinfomgt.2020.102211.

Franklin, D., \& Marshall, R. 2019. Adding Co-Creation as An Antecedent Condition Leading to Trust in Business-To-Business Relationships. Industrial Marketing Management, 77(October), 170-181. Https:// Doi.Org/10.1016/J.Indmarman.2018.10.002

Friedman, B. M. 1999. The Future of Monetary Policy: The Central Bank as An Army With Only A Signal Corps? International Finance, 2(3), 321-338. Https://Doi.Org/10.1111/1468-2362.00032.

Gefen, K., \& Straub. 2003. Gefen, Karahantrust And TAM In Online Shopping: An Integrated Model. MIS Quarterly, 27(1), 51. Doi:10.2307/30036519 
Gupta, K. P., Manrai, R., \& Goel, U. 2019. Factors in Fl Uencing Adoption of Payments Banks by Indian Customers : Extending UTAUT With Perceived Credibility. 13(2), 173-195. Https://Doi.Org/10.1108/ JABS-07-2017-0111

Hepola, J., Karjaluoto, H., \& Shaikh, A. 2016. Consumer Engagement and Behavioural Intention Towards The Continuous Use of Innovative Mobile Banking Applications - Case Study of Finland. International Conference On Information Systems (ICIS-2016), 11-14.

Lee, C.-P., Huang, T.-Y., 2014. E-Government Use and Citizen Empowerment: Examining The Effects of Online Information on Political Efficacy. Electron. J. Egovern. 12 (1), 52-64

Lin, H. H., \& Wang, Y. S. 2006. An Examination of The Determinants of Customer Loyalty in Mobile Commerce Contexts. Information and Management, 43(3), 271-282. Https: //Doi.Org/10.1016/J.Im.2005.08.001

Moeller, J., De Vreese, C., Esser, F. and Kunz, R., 2014. Pathway to Political Participation: The Influence of Online and Offline News Media on Internal Efficacy and Turnout of First-time Voters. American behavioral scientist, 58(5), pp.689-700. Doi:10.1177/ 0002764213515220

Monica, C., \& Briliana, V. 2019. Faktor-Faktor yang Mempengaruhi Continuance Intention Pengguna Go-Food di Jakarta. Jurnal Wira Ekonomi Mikroskil: JWEM, Vol. 9, No. 02, 115-126.

Montoro, L., Useche, S. A., Alonso, F., Lijarcio, I., Bosó-Seguí, P., \& Martí-Belda, A. 2019. Perceived Safety and Attributed Value As Predictors of The Intention to Use Autonomous Vehicles: A National Study With Spanish Drivers. Safety Science, 120(June), 865-876. Https://Doi.Org/10.1016/J.Ssci.2019.07.041

Muñoz-Leiva, F., Climent-Climent, S., \& Liébana-Cabanillas, F. 2017. Determinantes De La Intención De Uso De Las Aplicaciones De Banca Para Móviles: Una Extensión Del Modelo TAM Clásico. Spanish Journal Of Marketing - ESIC, 21(1), 25-38. Https://Doi.Org/10.1016/ J.Sjme.2016.12.001

Ng, D., \& Ng, D. 2017. Evolution of Digital Payments : Early Learnings From Singapore' S Cashless Payment Drive. 11(4), 306-313.

Noort, G. V., Kerkhof, P., \& Fennis, B. M. 2008. The Persuasiveness of Online Safety Cues: The Impact of Prevention Focus Compatibility of Web Content on Consumers' Risk Perceptions, Attitudes, and Intentions. Journal of Interactive Marketing, 22(4), 58-72. Doi: 10.1002/Dir.20121

Odoom, R., \& Kosiba, J. P. 2020. Mobile Money Usage and Continuance Intention Among Micro Enterprises in An Emerging Market - The Mediating Role of Agent Credibility. 22(1), 97-117. Https://Doi.Org/10.1108/ JSIT-03-2019-0062

Oliveira, T., Thomas, M., Baptista, G., \& Campos, F. 2016. Mobile Payment: Understanding The Determinants of Customer Adoption and Intention To Recommend The Technology. Computers in Human Behavior, 61(2016), 404-414. Https://Doi.Org/10.1016/J.Chb. 2016.03.030

Ozturk, A. B. 2016. Customer Acceptance of Cashless Payment Systems in The Hospitality Industry. 28(4), 801-817. Https://Doi.Org/10.1108/IJCHM-02-2015-0073

Sheller, M. 2004. Mobile Publics: Beyond The Network Perspective. Environment and Planning D: Society And Space, 22(1), 39-52. Https://Doi.Org/10.1068/D324t

Sobti, N., 2019. Impact of Demonetization on Diffusion of Mobile Payment Service in India: Antecedents of Behavioral Intention and Adoption using Extended UTAUT Model. Journal of Advances in Management Research. Https://Doi.Org/ 10.1108/JAMR-09-2018-0086

Venkatesh, V., Morris, M., Hall, M., \& Davis, G. 2003. User Acceptance of Information Technology: Toward A Unified View. Misquartely, 27(3), 425-478.

Wang, S. 2020. The Effects of Risk Appraisal and Coping Appraisal on The Adoption Intention of M-Payment. 38(1), 21-33. Https://Doi.Org/10.1108/IJBM-10-2018-0272

Yang, Y. 2015. Understanding Perceived Risks in Mobile Payment Acceptance. 115(2), 253-269. Https://Doi. Org/10. 1108/IMDS-08-2014-0243

Yoon, C. 2009. The Effects of National Culture Values on Consumer Acceptance of E-Commerce: Online Shoppers in China. Information And Management, 46(5), 294-301. Https://Doi.Org/ 10.1016/J.Im.2009.06.001

You, S., Kim, J. H., Lee, S. H., Kamat, V., \& Robert, L. P. 2018. Enhancing Perceived Safety in Human-Robot Collaborative Construction Using Immersive Virtual Environments. Automation in Construction, 96(March 2017), 161-170. Https://Doi.Org/ 10.1016/J.Autcon.2018.09.008

Zhou, T., Lu, Y., \& Wang, B. 2010. Integrating TTF and UTAUT To Explain Mobile Banking User Adoption. Computers in Human Behavior, 26(4), 760-767. Https://Doi.Org/10.1016/J.Chb. 2010.01.013 